\title{
The effect of biofloc and clear water at low and high salinity concentration on growth performance and antioxidant response of wild juveniles of Atlantic white shrimp Penaeus setiferus
}

\author{
Manuel Valenzuela-Jiménez ${ }^{1,4}(\mathbb{D})$, Diana Aguilera-Rivera ${ }^{2}(\mathbb{D})$, Wilson Wasielesky Jr. ${ }^{1}$ \\ Idelette Hernández-López ${ }^{1}{ }^{\mathbb{D}}$, Gabriela Rodríguez-Fuentes ${ }^{3}{ }^{(\mathbb{D}}$, Claudia Durruty-Lagunes ${ }^{4}$ \\ Gerard Cuzon $^{1}$ \& \& Gabriela Gaxiola ${ }^{4}$ \\ ${ }^{1}$ PPGAq, Estação Marinha de Aquicultura, Instituto de Oceanografia \\ Universidade Federal do Rio Grande, Rio Grande, Brasil \\ ${ }^{2}$ Escuela Nacional de Estudios Superiores, Unidad Mérida, UNAM, Mérida, Yucatán, México \\ ${ }^{3}$ Unidad de Química de Sisal, Facultad de Química, UNAM, México \\ ${ }^{4}$ Unidad Multidisciplinaria de Docencia e Investigación de Sisal, Facultad de Ciencias, UNAM, México \\ Corresponding author: Gabriela Gaxiola (mggc@ ciencias.unam.mx)
}

\begin{abstract}
The effect of biofloc (BFT) and clear water (CW) at low (ls) and high-water salinity (hs) in wild juveniles of Penaeus setiferus were evaluated. Four treatments were implemented: hsBFT, lsBFT, hsCW, and lsCW. After 45 days, final weight (FW), weight gain (WG), hepatosomatic index (HSI), and survival rate (SR) were evaluated. Antioxidant activity in muscle and hepatopancreas were measured: superoxide dismutase (SOD), catalase (CAT), glutathione-S transferase (GST), lipid peroxidation (LPO), protein oxidation (PO). The FW and SR was low for lsCW $(P<0.05)$, whereas the WG and HSI was high in hsBFT and lsBFT $(P<0.05)$. The integrative biomarker response index (IBR) showed differences between muscle (M) and hepatopancreas (HP). Results showed an increase of SOD and CAT measured from HP for lsBFT treatment. For M, CAT and GST were high only in BFT (regardless of the water salinity). LPO determined from $\mathrm{M}$ and HP recorded the high values at hs and ls, respectively. The PO determined in HP showed substantial damage in BFT (regardless of the salinity), whereas the same determination from $\mathrm{M}$ was only important for $1 \mathrm{sCW}$ treatment. When the analyses of variance (ANOVA) were performed, SOD, LPO, and PO were significant in response to salinity $(P<0.05)$. In contrast, for CAT, the higher activity was due to the rearing system and salinity interaction $(P<0.05)$. Results suggest that BFT could diminish the stress by stimulating the antioxidant system to maintain the redox balance through a higher enzyme activity and decrease damage in the proteins and lipids of the cells.
\end{abstract}

Keywords: Penaeus setiferus; biofloc; salinity; antioxidant activity; oxidative damage; biomarker response index

\section{INTRODUCTION}

In the southern Gulf of Mexico, Penaeus setiferus (Linnaeus, 1767) is exposed to a wide range of environmental pressures, including overfishing, pollution of coastal bays, estuaries, and lagoons with pesticides associated with agriculture, sewage discharge from coastal cities, or the petroleum industry operating in Campeche Bay (Arreguín et al. 1997, Garcia \& Vázquez-Bader 1998, Rosas et al. 2004). P. setiferus also presents serious deterioration of the reproductive quality of males (Rosas et al. 2004) in captivity and the natural environment. The indiscriminate global transfer of aquatic animals has been responsible for introducing, establishing, and disseminating many pathogens to new geographic areas (Briggs et al. 2005). In addition, the development of shrimp farms is based on widely domesticated species that are usually exotic to many geographic regions, so it is necessary to develop domestication programs for native species to maintain their sustainability (Gaxiola et al. 2008). 
The rearing of $P$. setiferus is an alternative not only for production purposes but also for conservation purposes for itself and other native species through sustainable biotechnologies (Valenzuela 2009). Several experiments have been carried out in the northern Gulf of Mexico, mainly focused on bait production for sport fishing (Sandifer et al. 1993, Samocha et al. 1998, Gandy et al. 2001). In these studies, the growth was slightly less than that of the commonly harvested $P$. vannamei (king prawn; Wakida-Kusunoki et al. 2011); however, P. setiferus is less sensitive to viral diseases and low salinities (Sandifer et al. 1993, Chapman et al. 2004). Moreover, P. setiferus does not represent an escape risk in the region associated with natural disasters such as floods caused by hurricanes or tropical storms in the Gulf of Mexico (Laramore et al. 2001, Valenzuela et al. 2002).

Salinity is the most important abiotic factor affecting the growth and survival of penaeid shrimp except for temperature (Kumlu et al. 2000). The idea that aquatic organisms exhibit better growth under a constant optimal salinity than under fluctuating conditions seems to be widely accepted (Yuepeng et al. 2010). Several studies mention the advantages of using inland low salinity water, including its low cost of land, less strict environmental protection legislation (Atwood et al. 2003), and the location of shrimp farms at a distance from potentially contaminated coastal waters (Moya et al. 1999). However, these rearing systems may negatively affect the physiology and survival of penaeid shrimp (Jiang et al. 2000).

The performance of $P$. setiferus in captivity may improve with a sustainable alternative that offers a substantial amount of live food, such as biofloc technology (BFT). The BFT rearing system helps to maintain the water quality by providing constant and abundant aeration in the pond to keep organic matter in suspension. Heterotrophic bacteria colonize the waste particles and absorb nitrogen, phosphorus, and other soluble nutrients, maintaining the water quality (Otoshi et al. 2001, Wasielesky et al. 2006). An additional benefit is the presence of microbial protein, filtered by juveniles, along with organic carbon and nitrogenous waste (Avnimelech 2007, Ballester et al. 2007, Azim \& Little 2008, Avnimelech \& Kochba 2009). The nutritional and probiotic contribution of microorganisms in BFT strengthens the immune response and antioxidant status of shrimp rearing in this condition ( Ju et al. 2008, Xu \& Pan 2013, Aguilera-Rivera et al. 2014, 2018, 2019a,b, da Silva Martins et al. 2015.

Traditionally, the indicators of the success of a culture refer to growth performance, i.e. growth, survival, or feed conversion ratio. However, all these responses and the physiology, immunology, and biochemical mechanisms depend on the environmental conditions. For example, the immunological processes associated with physiological biochemistry will assist in evaluating the health status (Bachère et al. 1995, LeMoullac et al. 1998). Considering these types of variables would reveal the mechanisms that shrimp use to adapt to the culture medium and identify how such information can achieve optimal results for the species. Some cellular defense mechanisms in crustaceans depend on free radicals during phagocytosis and encapsulation in response to oxidative stress (Smith et al. 2003). Due to changes in environmental conditions, the aerobic metabolism of crustaceans generates reactive oxygen species (ROS) (Muñoz et al. 2000). A certain concentration of ROS is necessary for defense against microbial infections. ROS residues can result in severe cell damage and affect a crustacean's ability to maintain balance. One response mechanism is a lipidsoluble antioxidant system (LSAS), which includes glutathione peroxidase, superoxide dismutase (SOD), and catalase (CAT) (Ren et al. 2009, Zhou et al. 2009, Quiu et al. 2011, Song et al. 2015).

The objective of this study was to evaluate the effect of BFT and clear water (CW) at low and high salinity concentration on growth performance, in addition to the differences between the antioxidant activity and oxidetive damage measured in muscle (M) and hepatopancreas (HP) tissues of wild juveniles of $P$. setiferus.

\section{MATERIALS AND METHODS}

The experiment was carried out at Unidad Multidisciplinaria de Docencia e Investigación (UMDI), Facultad de Ciencias, Universidad Nacional Autónoma de México, Campus Sisal, located in northeastern coastal region of the state of Yucatán $\left(21^{\circ} 9^{\prime} 55.22^{\prime \prime} \mathrm{N}\right.$, $\left.90^{\circ} 1^{\prime} 54.93^{\prime \prime} \mathrm{W}\right)$ in Puerto de Abrigo, s/n en Sisal, Municipio de Hunucmá (Yucatán, México).

\section{Subjects of study, capture, and transportation to the laboratory}

A total of 350 Penaeus setiferus juveniles (5.75 \pm 1.96 g) were collected at Laguna de Términos in Campeche, México, and transported at a density of 2.5 ind L $^{-1}$ in 50 $\mathrm{L}$ transparent plastic bags with one third water and two parts $\mathrm{O}_{2}$. They were acclimatized in a $20 \mathrm{~m}^{3}$ tank with seawater salinity at 25 for 10 days.

Shrimp were separated into two groups to continue acclimation. The first group was acclimated to marine seawater (35) and the second at low-salinity (5). For both cases, salinity was adjusted at two ups over 10 days. At the end of salinity acclimation, the shrimp were distributed in $100 \mathrm{~L}$ fiberglass tanks at a density 
of 10 shrimp per tank (100 ind $\left.\mathrm{m}^{-3}\right)$. The initial wet weight (IW) was recorded using an Ohaus balance $(0.1$ $\mathrm{g}$ of precision).

\section{Experimental design and rearing conditions}

The experimental design consisted of four treatments with three replicates per treatment $(n=10$ shrimp per treatment): biofloc in high salinity water (hsBFT), biofloc in low salinity water (lsBFT); clear seawater in high salinity (hsCW) and, clearwater in low salinity (lsCW).

Fifty liters $(50 \%)$ of biofloc inoculum water was added for each tank (from the grow-out system) at a C:N ratio of 20:1 to obtain the BFT (Avnimelech 1999). The tanks were filled to their full capacity $(100 \mathrm{~L})$ with filtered marine seawater. During the experimental period, cane molasses was added as a source of organic carbon at a rate of $6 \mathrm{~g}$ of carbon (C) per gram of total ammonia nitrogen (TAN) when the ammonium reached $1 \mathrm{mg} \mathrm{L}^{-1}$, as described in Ebeling et al. (2006), Samocha et al. (2007) and Avnimelech \& Kochba (2009). In BFT tanks, the water lost by evaporation was replaced in tanks at $2 \%$. For $\mathrm{CW}$ treatments at high and low salinity, water was also filtered using a sand filter. Water exchange was adjusted to a daily renewal of $35 \%$.

On day 0 , salinity for the four treatments was stabilized at 35 and 5 (for high and low-salinity water, respectively). Feed was given five times per day at 3\% biomass; shrimp from each tank were weighed weekly to adjust the amount of commercial feed $(35 \% \mathrm{CP}$, Malta Clayton; Culiacán, Sinaloa, México). The experiment lasted 45 days.

\section{Water quality parameters}

Temperature $\left(\mathrm{T}^{\circ}\right)$, dissolved oxygen (DO), and $\mathrm{pH}$ were measured daily at 08:00, 16:00, 20:00, 24:00 and 04:00 $\mathrm{h}$ with a multiparameter $\mathrm{HACH}^{\mathrm{TM}}$ (model Sension6-Hq40; Loveland, Colorado, USA) that was calibrated for each salinity value, which was measured daily with a self-compensating refractometer (Fisherbrand $^{\mathrm{TM}}$, Fisher Scientific Company; Ottawa, Canada). Every three days, suspended solids in tanks were collected and sedimented using Imhoff ${ }^{\circledR}$ cones (Aquatic Ecosystems Inc. ${ }^{\circledR}$ ) (Avnimelech et al. 2008). Water samples were collected for ammonia $\left(\mathrm{NH}_{4}\right)$, nitrite $\left(\mathrm{NO}_{2}\right)$, and nitrate $\left(\mathrm{NO}_{3}\right)$ analyses. Which were performed every week with a $\mathrm{HACH}^{\mathrm{TM}}$ colorimetric test kit (model NI-SA; Loveland, Colorado, USA) using the manufacturer's method for measuring diluted and full seawater (IOC 1983, APHA 2012). In addition, the chemical composition of hsCW and lsCW treatments was determined: hardness, alkalinity, ions concentration $\left(\mathrm{Na}^{+}, \mathrm{K}^{+}, \mathrm{Ca}^{+2}, \mathrm{Mg}^{+2}, \mathrm{Cl}^{-}, \mathrm{SO}_{4}^{-2}\right)$, according to
Geochemical and Environmental Quality Laboratory (Sisal, Yucatán) protocols.

\section{Growth performance}

At the end of the experiment, all shrimp from the four treatments were weighed and counted to estimate the growth performance (Cruz-Suárez et al. 2009):

$$
\begin{gathered}
W G=\left[\left(\begin{array}{c}
\text { average individual final weight } \\
\text {-average individual initial weight } \\
\text { average individual initial weight }
\end{array}\right)\right] \times 100 \\
H S I=\left(\frac{\text { hepatopancreas }(\mathrm{g})}{\text { individual weight }(\mathrm{g})}\right) \times 100 \\
S R=\left(\frac{\text { final number }}{\text { initial number }}\right) \times 100
\end{gathered}
$$

where WG: weight gain, HSI: hepatosomatic index, and SR: survival rate.

\section{Sampling}

At the end of the experiment, 30 shrimp from each treatment and at the intermolt stage (Corteel et al. 2012) were placed in freezing water at $5.0^{\circ} \mathrm{C}$ below the initial temperature to decrease their metabolic activity (Pascual et al. 2003). They were transported to the laboratory for analysis. For each shrimp, $100 \mu \mathrm{L}$ of hemolymph was collected from the ventral sinus using a $30 \mathrm{G} \times 13 \mathrm{~mm}$ syringe preloaded with SIC-EDTA anticoagulant ( $\mathrm{NaCl} 450 \mathrm{mM}, \mathrm{KCl} 10 \mathrm{mM}$, HEPES 10 mM, EDTA $10 \mathrm{mM}$; pH 7.3). Hemolymph was placed in a hematocytometer glass for THC determination (Automated cell counter, model TC20 ${ }^{\mathrm{TM}}$, BIO-RAD, Philadelphia, PA, USA). A portion of M and HP tissue was stored at $-80^{\circ} \mathrm{C}$ for further analysis.

\section{Homogenate preparation}

One hundred milligrams of $\mathrm{M}$ and $\mathrm{HP}$ samples previously-stored at $-80^{\circ} \mathrm{C}$ were cold macerated using $1000 \mu \mathrm{L}$ of $0.05 \mathrm{M}$ Tris buffer (pH 7.4). Then, $500 \mu \mathrm{L}$ of the obtained homogenate was separated and centrifuged at $1000 \mathrm{~g}$ for $5 \mathrm{~min}$ at $4.0^{\circ} \mathrm{C}$ to determine superoxide dismutase (SOD), catalase (CAT), and glutathione S-transferase (GST) enzymes. Whereas 500 $\mu \mathrm{L}$ of the non-centrifuged homogenate was used to evaluate lipid and protein oxidation (LPO and PO). All analyses were evaluated using $10 \mu \mathrm{L}$ of homogenized preparations by triplicate, reading the absorbance in 96well plates using a spectrophotometer (PerkinElmer ${ }^{\odot}$, Waltham, Massachusetts, USA).

\section{Antioxidant activity}

SOD activity from M (SOD-M) and HP (SOD-HP) samples were quantified with a commercial kit (SigmaAldrich, St. Louis, MO, USA). One unit was defined as 
the amount of enzyme required to inhibit $50 \%$ of xanthine activity in $20 \mathrm{~min}$, and the absorbance was measured at 450 nm. CAT activity (Hadwan \& Abed 2016) was measured from M (CAT-M), and HP (CAT-HP) tissues using a microplate assay. Samples were incubated in two 96-well plates with $100 \mu \mathrm{L}$ of phosphate buffer (pH 7.4) or $100 \mu \mathrm{L}$ of the same buffer with $\mathrm{H}_{2} \mathrm{O}_{2}$; both microplates were incubated for $3 \mathrm{~min}$, and the reaction was stopped by the addition of $100 \mu \mathrm{L}$ of ammonium molybdate. The absorbance was measured at $450 \mathrm{~nm}$, and the amounts of both enzymes are expressed as $\mathrm{U}$ mg protein ${ }^{-1}$. GST activity in M (GST-M) was evaluated with a microplate method using $190 \mu \mathrm{L}$ of Na phosphate buffer; $200 \mathrm{mM}$ reduced glutathione plus 1-chloro-2,4-dinitrobenzene was added to a final concentration of $100 \mathrm{mM}$, and the absorbance was read at $412 \mathrm{~nm}$ after $5 \mathrm{~min}$. The activity was calculated using an extinction coefficient of $E=9.6$ $\mathrm{mM}^{-1} \mathrm{~cm}^{-1}$; all results are expressed in nmol $\mathrm{mg}^{-1}$ protein $\min ^{-1}$ (Contreras-Vergara et al. 2007).

The total protein content in the $\mathrm{M}$ and HP supernatants was tested using a microplate assay with a dye reagent concentrate (Bio-Rad, Philadelphia, PA, USA). The bovine serum albumin (BSA) solution (EMD Biosciences, Inc., La Jolla, CA, USA) was used as a standard according to Bradford (1976). The absorbance was measured at $595 \mathrm{~nm}$.

\section{Oxidative damage}

LPO from M (LPO-M) and HP (LPO-HP) samples were quantified (Fox et al. 1994) using the PeroxiDetect ${ }^{\oplus}$ kit (Sigma-Aldrich, St. Louis, MO, USA) after extraction without centrifugation, homogenization with methanol 1:1 (v/v) and centrifugation at an RCF of $10,000 \mathrm{~g}$ for $5 \mathrm{~min}$ at $27^{\circ} \mathrm{C}$. Then, $10 \mu \mathrm{L}$ of the extract was placed in two 96-well plates, and $160 \mu \mathrm{L}$ of the working solution was added. The samples were incubated for $60 \mathrm{~min}$, and the absorbance was measured at $595 \mathrm{~nm}$. A standard curve was prepared using serial dilutions with $129 \mu \mathrm{L}$ of $1 \mathrm{M}$ tert-butyl hydroperoxide (TBOOH) plus $871 \mu \mathrm{L}$ of methanol (results expressed in nmol peroxide $\mathrm{mL}^{-1}$ ).

Moreover, the PO level from M (PO-M) and HP (PO-HP) tissues were evaluated (Mesquita et al. 2014) by adding $100 \mu \mathrm{L}$ of dinitrophenyl hydrazine (DNPH) plus $2 \mathrm{~N} \mathrm{HCl}$ combined with $100 \mu \mathrm{L}$ of Tris buffer $\mathrm{pH}$ 7.4 (blank) or $100 \mu \mathrm{L}$ of the homogenized solution, without centrifugation, to Eppendorf ${ }^{\ominus}$ tubes, which were incubated for $10 \mathrm{~min}$. Then, $50 \mu \mathrm{L}$ of $6 \mathrm{M} \mathrm{NaOH}$ was added to the samples and blank. All tubes were centrifuged at an RCF of $10,000 \mathrm{~g}$ for $5 \mathrm{~min}$ at $27^{\circ} \mathrm{C}$. Finally, $150 \mu \mathrm{L}$ of each sample and the blank were added to a 96-well plate. The absorbance was read at 450 $\mathrm{nm}$. The results are expressed in nmol mg protein ${ }^{-1}$.

\section{Integrative biomarker index}

Nine biomarkers (SOD-M, SOD-HP, CAT-M, CAT-HP, GST-M, LPO-M, LPO-HP, PO-M, PO-HP) were integrated with a method that combines several biomarker responses into a general "stress index" denominated integrative biomarker response index (IBR) (Beliaeff \& Burgeot 2002). The IBR was calculated according to Xie et al. (2016):

1) Calculation of mean and standard deviation for each biomarker of the treatments.

2) Standardization of data: $Y=(X-m) s^{-1}$, where $Y$ : standardized value of the biomarker, $X$ : the value of each biomarker response, $\mathrm{m}$ : mean value of the biomarker.

3) The score ( $S$ ): $S=Y+|\min |$, where $S \geq 0$ and $|\min |$ : absolute minimum value of $\mathrm{Y}$ for each biomarker.

The score of biomarkers was visualized using a stat plot in which the radial coordinate corresponded to the score. All graphs were produced using Microsoft ${ }^{\mathrm{TM}}$ Excel $^{\mathrm{TM}}$ for Office 365 MSO.

\section{Statistical analysis}

All graphs and statistical analyses were conducted using R Statistical Software (R Core Team, 2018). Results were expressed as mean \pm standard error (SE). After the normality of data was verified by the ShapiroWilk test and homoscedasticity by the Bartlett test. Subsequently, bifactorial ANOVA of $2 \times 2$ was used to determine the interaction between the rearing system (BFT, CW) and low (ls) and high-water salinity (hs). If the primary effect was significant, the ANOVA was followed by Tukey's test. When data were not homogeneous, a Wilcoxon Rank-Sum test was performed to determine differences between treatments. The significance level was set at 0.05 .

\section{Ethical approval}

The authors followed all applicable international, national, and institutional guidelines for the care and use of animals.

\section{RESULTS}

\section{Water quality parameters}

All water quality parameters for both rearing systems at high and low salinity remained within the recommended levels for shrimp reared through the 45 days of the experiment (Table 1). Due to the low survival in hsCW and lsCW treatments, chemical composition performed in water showed a lower ion concentration of $\mathrm{K}^{+}$and $\mathrm{Mg}^{+2}$ only for lsCW (Table 2).

\section{Growth performance}

The results related to the growth performance (Table 3) of wild Penaeus setiferus juveniles after 45 days experiment recorded the higher FW (g) and WG (g) for 
Table 1. Water quality parameters for both rearing systems at high and low salinity during 45 days of the experiment. Each value represents the mean \pm standard deviation. DO: dissolved oxygen, hsBFT: biofloc at high salinity, lsBFT: biofloc at low salinity, hsCW: clear water at high salinity, lsCW: clear water at low salinity, n/a: analysis not applicable.

\begin{tabular}{lccccccc}
\hline Treatment & $\begin{array}{c}\mathrm{DO} \\
\left(\mathrm{mg} \mathrm{L}^{-1)}\right.\end{array}$ & $\begin{array}{c}\text { Temperature } \\
\left({ }^{\circ} \mathrm{C}\right)\end{array}$ & $\mathrm{pH}$ & Salinity & $\begin{array}{c}\mathrm{NH}_{4} \\
\left(\mathrm{mg} \mathrm{L}^{-1}\right)\end{array}$ & $\begin{array}{c}\mathrm{NO}_{2} \\
\left(\mathrm{mg} \mathrm{L}^{-1)}\right.\end{array}$ & $\begin{array}{c}\mathrm{NO}_{3} \\
\left(\mathrm{mg} \mathrm{L}^{-1}\right)\end{array}$ \\
\hline hsBFT & $7.1 \pm 0.5$ & $26.5 \pm 0.9$ & $7.4 \pm 0.6$ & $34.7 \pm 1.4$ & $0.4 \pm 0.5$ & $1.4 \pm 1.2$ & $82.4 \pm 25.2$ \\
lsBFT & $7.3 \pm 0.3$ & $26.4 \pm 1.0$ & $8.6 \pm 0.5$ & $5.9 \pm 2.0$ & $0.7 \pm 0.26$ & $3.9 \pm 2.2$ & $53.5 \pm 18.5$ \\
hsCW & $7.2 \pm 0.6$ & $26.6 \pm 0.7$ & $8.2 \pm 0.6$ & $35 \pm 0.4$ & $\mathrm{n} / \mathrm{a}$ & $\mathrm{n} / \mathrm{a}$ & $\mathrm{n} / \mathrm{a}$ \\
lsCW & $7.25 \pm 0.3$ & $26.8 \pm 0.7$ & $7.8 \pm 0.4$ & $5.82 \pm 3.9$ & $\mathrm{n} / \mathrm{a}$ & $\mathrm{n} / \mathrm{a}$ & $\mathrm{n} / \mathrm{a}$ \\
\hline
\end{tabular}

Table 2. Chemical composition of the water used for clear water at high salinity (hsCW) and clear water at low salinity (lsCW) treatments during 45 days of the experiment.

\begin{tabular}{|c|c|c|}
\hline & $\mathrm{hsCW}$ & $1 \mathrm{sCW}$ \\
\hline Hardness $\left(\mathrm{mg} \mathrm{CaCO}_{3} \mathrm{~L}^{-1}\right)$ & 6361.9 & 734.5 \\
\hline Alkalinity $\left(\mathrm{mg} \mathrm{CaCO}_{3} \mathrm{~L}^{-1}\right)$ & 114.8 & 333.7 \\
\hline $\mathrm{Na}^{+}\left(\mathrm{mg} \mathrm{L}^{-1}\right)$ & 11490 & 693 \\
\hline $\mathrm{K}^{+}\left(\mathrm{mg} \mathrm{L}^{-1}\right)$ & 432.4 & 24.7 \\
\hline $\mathrm{Ca}^{+2}\left(\mathrm{mg} \mathrm{L}^{-1}\right)$ & 380.4 & 141.8 \\
\hline $\mathrm{Mg}^{+2}\left(\mathrm{mg} \mathrm{L}^{-1}\right)$ & 1396 & 106.0 \\
\hline $\mathrm{Cl}^{-}\left(\mathrm{mg} \mathrm{L}^{-1}\right)$ & 15800 & 1200.0 \\
\hline $\mathrm{SO}_{4}^{-2}\left(\mathrm{mg} \mathrm{L}^{-1}\right)$ & 1380.21 & 74 \\
\hline
\end{tabular}

lsBFT, hsBFT, and hsCW treatments $(P<0.05)$. In contrast, the lowest HSI (\%) and SR (\%) were observed for low-salinity water used for both rearing conditions (BFT, CW) (Table 3).

\section{Antioxidant activity}

The activities of SOD, CAT, and GST enzymes measured in M and HP samples are shown (Fig. 1). When the SOD enzyme activity was evaluated with the IBR analyses, the higher activity was recorded in $\mathrm{M}$ and HP samples obtained from lsBFT and followed by lsCW treatment. In contrast, the lowest values were observed for hsCW and hsBFT in $\mathrm{M}$ and $\mathrm{H}$ tissue, respectively (Figs. 1a-b). SOD levels in $\mathrm{M}$ samples were similar between treatments $(P>0.05)$ (Table 4$)$. The levels increased significantly when the determination was performed with HP tissues and as a result of the water salinity factor $(P<0.05)$ (Table 4 , Fig. 2$)$.

As seen in Figure 1c, the CAT activity measured from $M$ tissue exhibited increase relatives to the BFT treatments (regardless of water salinity, whereas for the HP samples, the higher activity of the enzyme was maintained for hsCW and lsBFT (Fig. 1d). Significant CAT enzyme activity in $M$ was identified for interaction between the rearing system and the water salinity $(P<0.05)$. The higher activity in shrimp reared in lsBFT was observed, whereas for $1 \mathrm{sCW}$, and both rearing systems at hs (hsBFT, hsCW) treatments were statistically similar between them (Table 4, Fig. 3). In Figure 1e, no significant differences in GST activities in M and HP samples were observed by the effect of the rearing system or the water salinity $(P>0.05)$ (Table $4)$.

\section{Oxidative damage}

The oxidative damage related to LPO and PO measured in M, and HP tissues are shown (Fig. 4). As illustrated in Figure 4a, the higher LPO in M samples was related to low salinity in water (regardless of the rearing system), whereas for HP tissue, the higher LPO was recorded for high salinity water treatments (regardless of the rearing condition) (Fig. 4b). Only for HP samples, an increase of LPO was observed $(P<0.05)$ because of the water salinity condition (Table 5, Fig. 5).

Finally, the PO measured in $\mathrm{M}$ tissue was higher in lsCW treatment (Fig. 4c), whereas in HP samples, the PO was observed only in BFT treatments (regardless of water salinity) (Table 4, Fig. 4d). The PO exhibited an increase in M and HP samples always in response to the water salinity $(P<0.05)$ (Table 5, Figs. 6a-b).

\section{DISCUSSION}

The postlarvae and juveniles of Penaeus setiferus can develop much better in euryhaline environments since they have a better capacity for osmotic and ionic regulation than adults, which allows them to adapt to conditions of both high and very low salinity (Castille \& Lawrence 1980, Laramore et al. 2001). In this study, water salinity was maintained at 5 and 35, a known range for this species in the coastal lagoons where they were captured (Rozas \& Minello 2011). The water quality conditions, in general, were maintained at levels suitable for the culture of penaeid shrimp. The DO remained above $6.0 \mathrm{~mL} \mathrm{~L}^{-1}$, the temperature ranged between 26 and $27^{\circ} \mathrm{C}$. The $\mathrm{pH}$ values were maintained in the upper limits, but within what is established for these animals, due to the natural chemical composition of well water in the Yucatan Peninsula, which also has 
Table 3. Initial weight (IW), final weight (FW), weight gain (WG), hepatosomatic index (HSI), and survival rate (SR) for wild juveniles Penaeus setiferus after 45 days of the experiment. Each value represents the mean \pm standard deviation. According to the ANOVA test, different superscript letters within rows indicate significant differences among treatments $(P<0.05)$. hsBFT: biofloc at high salinity, lsBFT: biofloc at low salinity, hsCW: clear water at high salinity, lsCW: clear water at low salinity. ${ }^{*}$ : rearing system factor, ${ }^{* *}$ : salinity water factor.

\begin{tabular}{lccccc}
\hline Treatment & IW $(\mathrm{g})$ & FW $(\mathrm{g})$ & WG $(\mathrm{g})$ & HSI $(\%)$ & SR $(\%)$ \\
\hline hsBFT & $5.75 \pm 1.12$ & $9.28 \pm 2.48^{\mathrm{a}^{*}}$ & $3.53 \pm 0.53^{\mathrm{a}^{*}}$ & $4.19 \pm 1.17^{\mathrm{a}^{* *}}$ & $56.67^{* * *}$ \\
lsBFT & $5.78 \pm 1.26$ & $8.33 \pm 1.62^{\mathrm{a}^{*}}$ & $2.55 \pm 0.18^{\mathrm{b}}$ & $3.35 \pm 0.89^{\mathrm{b}}$ & $40^{\mathrm{b}}$ \\
hsCW & $5.23 \pm 0.96$ & $8.08 \pm 3.1^{\mathrm{a}^{*}}$ & $2.78 \pm 0.97^{\mathrm{a}^{*}}$ & $4.29 \pm 0.36^{\mathrm{a}^{* *}}$ & $60^{\mathrm{a}^{* *}}$ \\
lsCW & $5.96 \pm 1.75$ & $4.49 \pm 0.41^{\mathrm{b}}$ & $0.28 \pm 0.41^{\mathrm{b}}$ & $3.45 \pm 0.55^{\mathrm{b}}$ & $26.67^{\mathrm{b}}$ \\
\hline
\end{tabular}

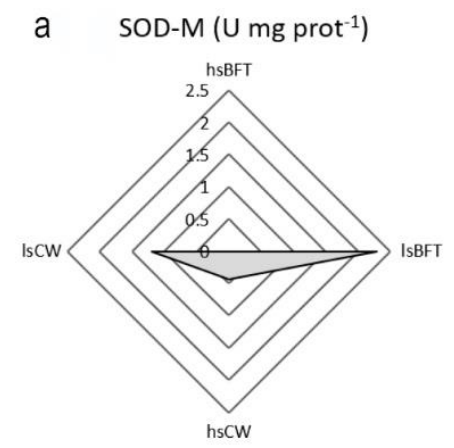

b SOD-HP $\left(U \mathrm{mg} \mathrm{prot}^{-1}\right)$

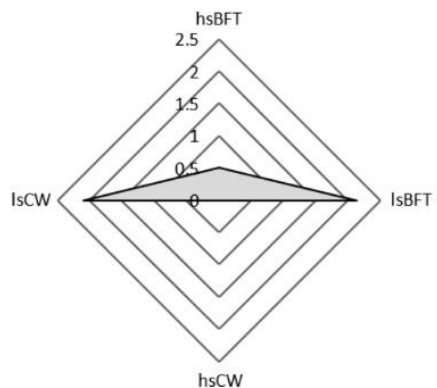

C $\quad$ CAT-M (U mg prot $\left.{ }^{-1}\right)$
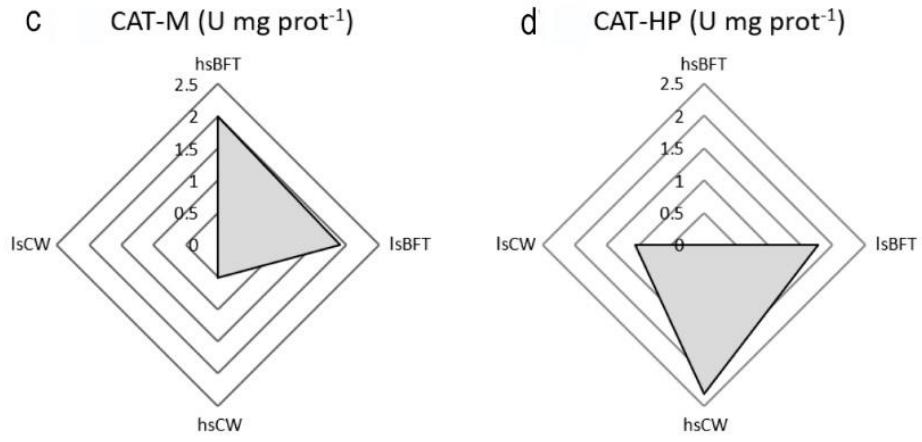

e . GST-M ( $\mathrm{nmol}$ min $\mathrm{mg} \operatorname{prot}^{-1}$ )

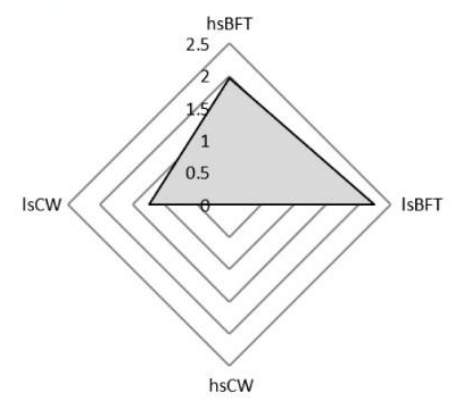

Figure 1. Integrated biomarker response (IBR) and stat plots for the following biomarkers: a) superoxide dismutase measured in muscle (SOD-M), b) superoxide dismutase measured in hepatopancreas (SOD-HP), c) catalase measured in muscle (CAT-M), d) catalase measured in hepatopancreas (CAT-HP), and e) glutathione-S transferase (GST-M) measured in wild juveniles' shrimp Penaeus setiferus and after 45 days of the experiment. hsBFT: biofloc at high salinity, lsBFT: biofloc at low salinity, hsCW: clear water at high salinity, lsCW: clear water at low salinity. 
Table 4. Superoxide dismutase (SOD), catalase (CAT), and glutathione-S transferase (GST) measured in muscle (M) and hepatopancreas (HP) of wild juveniles' shrimp Penaeus setiferus, according to the rearing system (BFT, CW) and water salinity (hs, ls) and after 45 days of the experiment. Each value represents the mean \pm standard deviation. According to the ANOVA test, different superscript letters within rows indicate significant differences among treatments $(P<0.05)$. hsBFT: biofloc at high salinity, lsBFT: biofloc at low salinity, hsCW: clear water at high salinity, lsCW: clear water at low salinity. $*$ : rearing system factor, $* *$ : water salinity factor, $* * *$ : interaction between factors.

\begin{tabular}{llcccc}
\hline \multirow{2}{*}{ Tissue } & \multirow{2}{*}{ Antioxidant activity } & hsBFT & hsCW & Treatment \\
\cline { 3 - 5 } & & lsBT & 1sCW \\
\hline M & SOD $\left(\mathrm{U} \mathrm{mg} \mathrm{prot}^{-1}\right)$ & $2.33 \pm 0.16^{\mathrm{a}}$ & $2.32 \pm 0.30^{\mathrm{a}}$ & $2.46 \pm 0.25^{\mathrm{a}}$ & $2.46 \pm 0.04^{\mathrm{a}}$ \\
& CAT $\left(\mathrm{U} \mathrm{mg} \mathrm{prot}^{-1}\right)$ & $0.85 \pm 0.14^{\mathrm{b}}$ & $0.86 \pm 0.16^{\mathrm{b}}$ & $1.01 \pm 0.27^{\text {****}}$ & $0.73 \pm 0.15^{\mathrm{b}}$ \\
& GST $\left(\mathrm{nmol} \operatorname{min~mg~prot~}^{-1}\right)$ & $1.30 \pm 0.25^{\mathrm{a}}$ & $1.20 \pm 0.27^{\mathrm{a}}$ & $1.34 \pm 0.24^{\mathrm{a}}$ & $1.27 \pm 0.15^{\mathrm{a}}$ \\
HP & SOD $\left(\mathrm{U} \mathrm{mg} \mathrm{prot}^{-1}\right)$ & $2.57 \pm 0.32^{\mathrm{b}}$ & $2.53 \pm 0.20^{\mathrm{b}}$ & $2.83 \pm 0.17^{\mathrm{a}^{* *}}$ & $2.74 \pm 0.15^{\mathrm{a}^{* *}}$ \\
& CAT $\left(\mathrm{U} \mathrm{mg} \mathrm{prot}^{-1}\right)$ & $0.97 \pm 0.59^{\mathrm{a}}$ & $0.91 \pm 0.50^{\mathrm{a}}$ & $1.23 \pm 0.53^{\mathrm{a}}$ & $1.13 \pm 0.62^{\mathrm{a}}$ \\
\hline
\end{tabular}

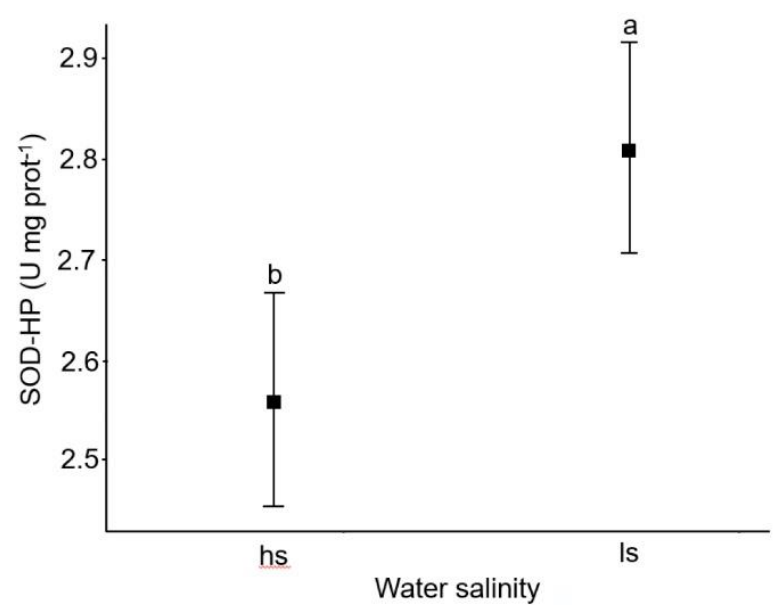

Figure 2. Principal factor effect by bifactorial ANOVA of $2 \times 2$ followed by Tukey's test for superoxide dismutase (SOD) enzyme in hepatopancreas (HP) of wild juveniles' shrimp Penaeus setiferus, according to the water salinity (high, low) and after 45 days of the experiment. hs: high salinity (35), ls: low salinity (5).

a high level of hardness and alkalinity (Van Wyk \& Scarpa 1999, Laramore et al. 2001, Rozas \& Minello 2011). Ammonium, nitrite, and nitrate in BFT treatments were maintained within the normal limits for this type of rearing system (Lin \& Chen 2001, Campos et al. 2012, da Silva Martins et al. 2015, Prangnell \& Castro 2016, Samocha et al. 2017, De Souza et al. 2019).

Shrimp from high salinity water (hs) treatments showed higher weight and percentage of HSI during the experiment (hsBFT and hsCW). It could indicate that animals in low salinity spent a greater amount of energy to stay alive (routine metabolism); this corroborated with the low food consumption, as they have the lowest survival rate (40 and $27 \%$ for $1 \mathrm{sBFT}$ and $1 \mathrm{sCW}$, respectively). The low survival and growth of treatments at low salinity water could be affected by the potassium

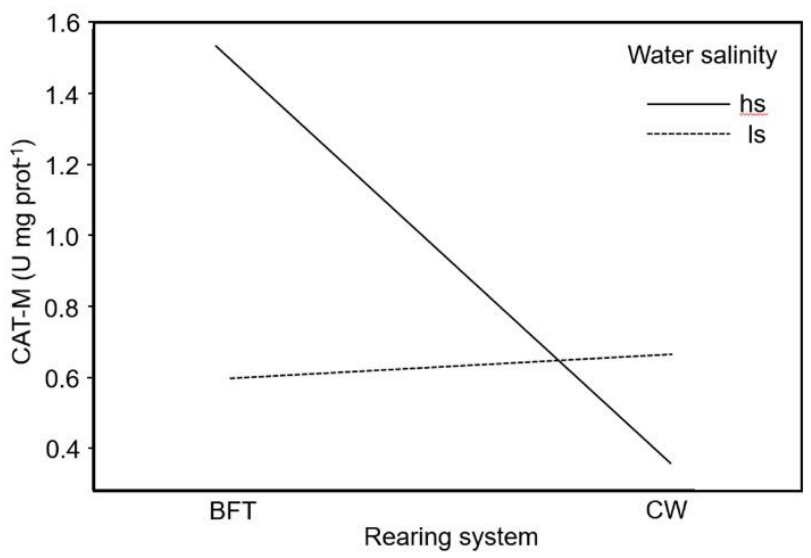

Figure 3. Interaction obtained by bifactorial ANOVA of $2 \times 2$ followed by Tukey's test for catalase (CAT) enzyme activity in muscle (M) of wild juveniles' shrimp Penaeus setiferus, according to the rearing system (BFT, CW) and water salinity (hs, ls) and after 45 days of the experiment. hs: high salinity (35), ls: low salinity (5), BFT: biofloc, CW: clear water.

concentration in the water and magnesium's lesser degree (Davis et al. 2002, Saoud et al. 2003, McNevin et al. 2004). For this reason, the addition of both elements in low salinity water could enhance the survival and growth of postlarvae (Davis et al. 2005, Roy et al. 2007).

The HSI values were significantly higher $(P<0.05)$ for treatments with high salinity (hs), probably attributed to a better capacity to store and assimilate nutrients, which can be reflected in better nutritional and physiological conditions and, therefore, a higher increase in weight. It is most likely that in the lowsalinity water treatments (ls), the nutrients were being used by the shrimp to maintain their daily metabolism and survival requirements rather than being used for growth. In addition, it is important to mention that wild shrimp P. setiferus for CW treatments presented diffi- 

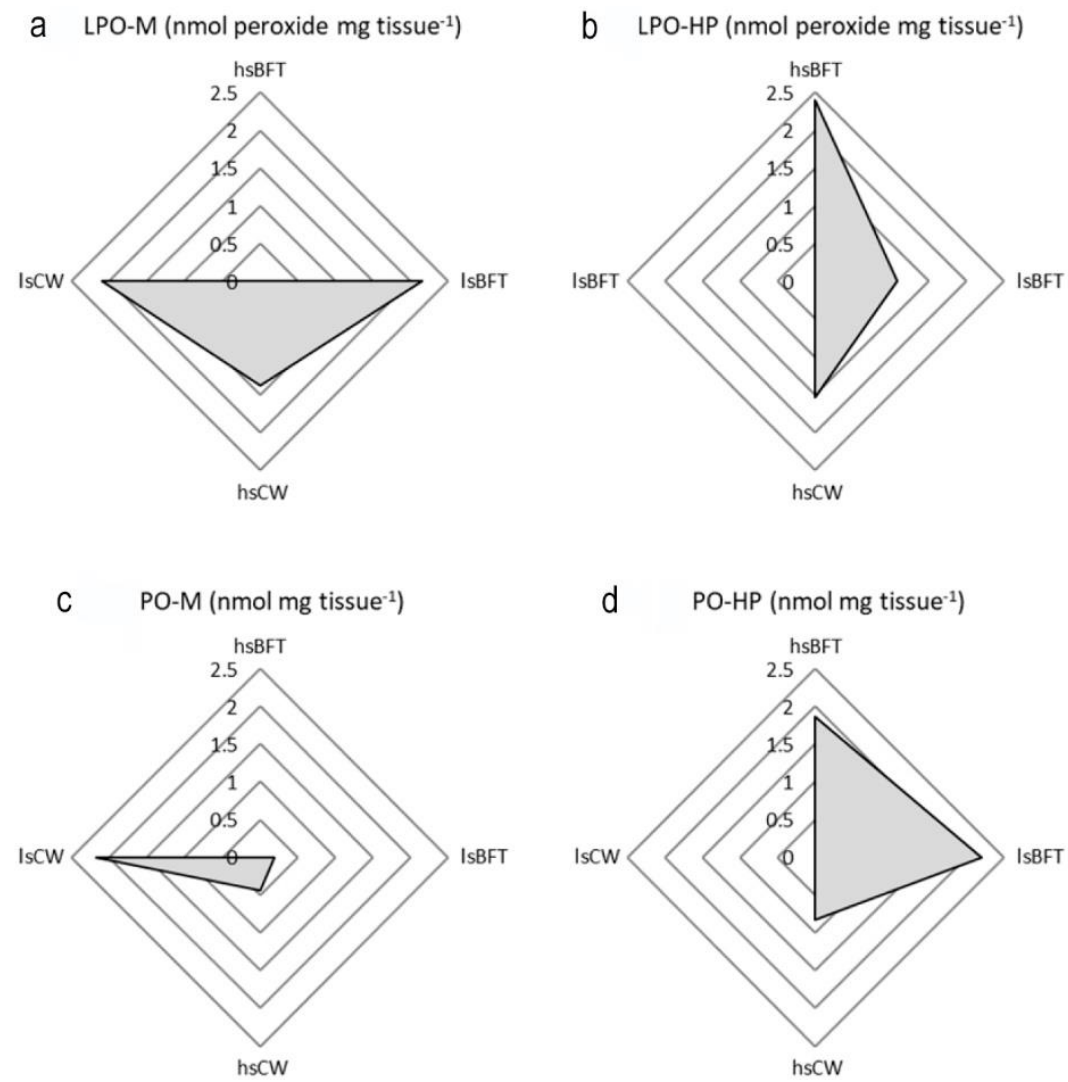

Figure 4. Integrated biomarker response (IBR) and stat plots for the following biomarkers: a) lipid peroxidation measured in muscle (LPO-M), b) lipid peroxidation measured in hepatopancreas (LPO-HP), c) protein oxidation measured in muscle (PO-M), and d) protein oxidation measured in hepatopancreas (PO-HP) of wild juveniles' shrimp Penaeus setiferus and after 45 days of the experiment. hsBFT: biofloc at high salinity, lsBFT: biofloc at low salinity, hsCW: clear water at high salinity, lsCW: clear water at low salinity.

Table 5. Lipid peroxidation (LPO) and protein oxidation (PO) measured in muscle (M) and hepatopancreas (HP) of wild juveniles' shrimp Penaeus setiferus, according to the rearing system (BFT, CW) and water salinity (hs, ls) and after 45 days of the experiment. Each value represents the mean \pm standard deviation. According to the ANOVA test, different superscript letters within rows indicate significant differences among treatments $(P<0.05)$. hsBFT: biofloc at high salinity, lsBFT: biofloc at low salinity, hsCW: clear water at high salinity, lsCW: clear water at low salinity. *: rearing system factor, **: water salinity factor.

\begin{tabular}{|c|c|c|c|c|c|}
\hline \multirow{2}{*}{ Tissue } & \multirow{2}{*}{ Oxidative damage } & \multicolumn{4}{|c|}{ Treatment } \\
\hline & & hsBFT & hsCW & lsBFT & lsCW \\
\hline $\mathrm{M}$ & LPO (nmol peroxide mg tis & $0.63 \pm 0.31^{\mathrm{a}}$ & $0.76 \pm 0.35^{\mathrm{a}}$ & $0.84 \pm 0.41^{\mathrm{a}}$ & $0.83 \pm 0.48^{\mathrm{a}}$ \\
\hline & $\mathrm{PO}(\mathrm{n}$ & $3.89 \pm 0.32^{2^{* *}}$ & $3.94 \pm 0.32^{\mathrm{a}^{* *}}$ & $3.33 \pm 0.38^{\mathrm{b}}$ & $1.34 \pm 0.02^{\mathrm{b}}$ \\
\hline HP & LPO (nmol peroxide mg tissue $\left.{ }^{-1}\right)$ & $1.17 \pm 0.31^{\mathrm{a}^{* *}}$ & $1.00 \pm 0.21^{* * *}$ & $0.91 \pm 0.20^{\mathrm{b}}$ & $0.70 \pm 0.14^{\mathrm{b}}$ \\
\hline & $\mathrm{PO}$ (nmol mg tissue & $1.77 \pm 0.57^{\mathrm{b}}$ & $1.99 \pm 034^{\mathrm{b}}$ & $2.37 \pm 0.41^{\mathrm{a}^{*}}$ & $2.64 \pm 0.47^{\mathrm{a}^{* *}}$ \\
\hline
\end{tabular}

culties in acclimatizing to a fixed change of salinity and a constant flow of water in this rearing system.

BFT rearing systems have been demonstrated to increase the growth, survival, and reproductive capacity of shrimp. According to Emerenciano et al. (2012) and Ekasari et al. (2013), BFT contains a wide range of nutrients, particularly proteins, of microbial origin
(Tacon et al. 2002, Wasielesky et al. 2006, Kuhn et al. 2008). Which stimulates the immune and antioxidant system of shrimp (Xu \& Pan 2013, Cardona et al. 2015, Zhao et al. 2016, Aguilera-Rivera et al. 2018) and even functions as a natural probiotic (Castex et al. 2010, Aguilera-Rivera et al. 2014, Soltes-Ferreira et al. 2015). 


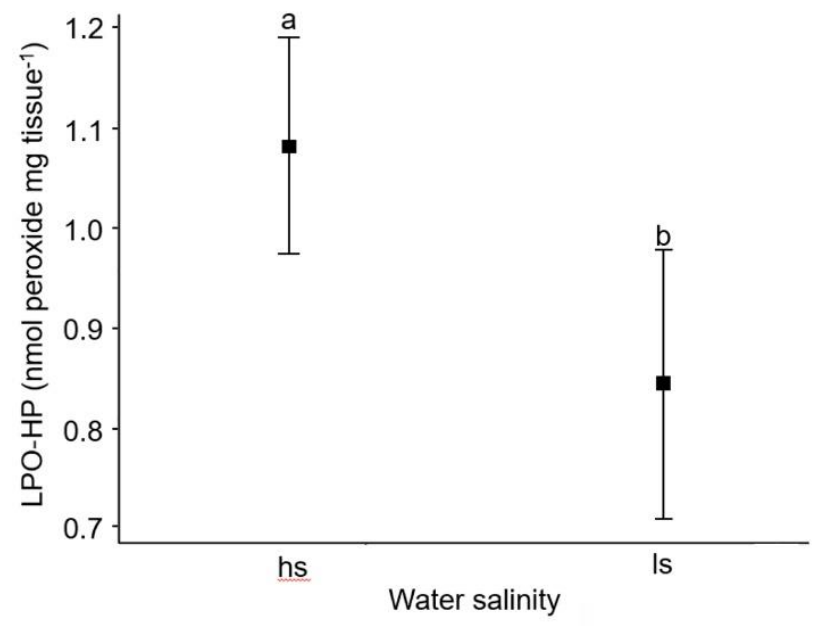

Figure 5. Principal factor effect by bifactorial ANOVA of $2 \times 2$ followed by Tukey's test for lipid peroxidation (LPO) produced in hepatopancreas (HP) of wild juveniles' shrimp Penaeus setiferus, according to the water salinity (high, low) and after 45 days of the experiment. hs: high salinity (35), ls: low salinity (5).

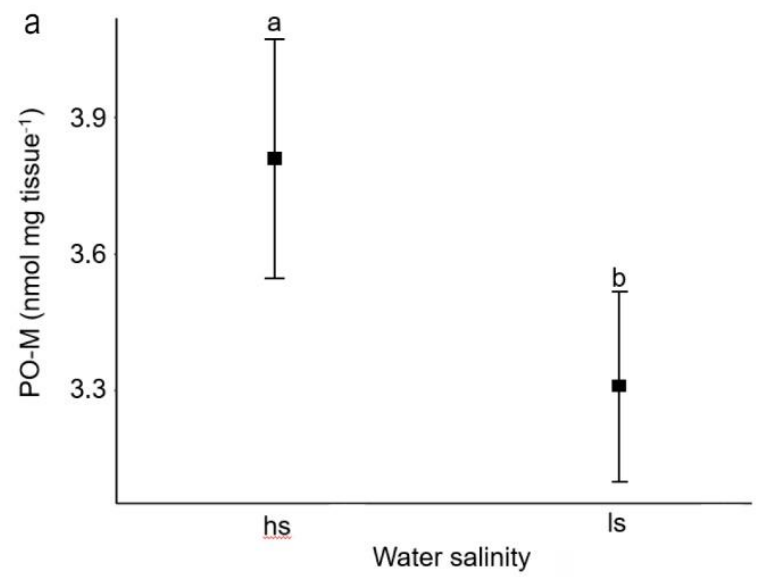

The lowest growth occurred in the lsCW treatment, along with the lowest SR (\%). The difficulty of the wild juveniles to acclimatize to low salinity conditions with constant water exchange was notable.

Perhaps the constant flow of water prevented them from adapting early on to captivity conditions. According to Castille \& Lawrence (1980) and Rozas \& Minello (2011), animals move continuously within different salinity gradients and do not remain in only one. Due to the low survival for seawater treatments (lsBFT and lsCW), the ionic content of the water was tested, showing a very low concentration of $\mathrm{K}^{+}$and $\mathrm{Mg}^{+2}$ ions. Probably affected the metabolism of shrimp by the inactivation of the $\mathrm{Na}^{+} / \mathrm{K}^{+}$-ATPase enzyme and the osmoregulatory capacity of cells (by the low levels of $\mathrm{K}^{+}$), or producing an inefficient enzyme activation, cellular regeneration, and carbohydrate assimilation (by the low levels of $\mathrm{Mg}^{+2}$ ) (Roy et al. 2007, 2010). For this reason, some studies suggest the addition of potassium and magnesium fertilizers to increase the concentration of both elements for inland shrimp farms (Boyd \& Thunjai 2003).

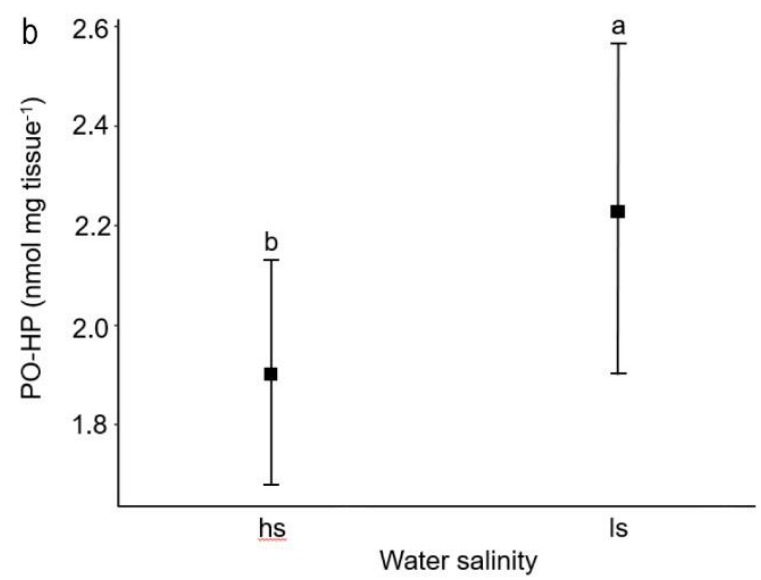

Figure 6. Principal factor effect by bifactorial ANOVA of $2 \times 2$ followed by Tukey's test for protein oxidation (PO) produced in a) muscle (M) and b) hepatopancreas (HP) of wild juveniles' shrimp Penaeus setiferus, according to the water salinity (high, low) and after 45 days of the experiment. hs: high salinity (35), ls: low salinity (5).

The antioxidant system has a crucial function in the balance of ROS production and control of oxidative stress. This system is regulated by enzymatic (such as SOD and CAT) and non-enzymatic (such as GST) mechanisms, which helps to prevent the damage in cells due to the excess of ROS in tissues (Ren et al. 2015). In this study, SOD, CAT, and GST were measured in muscle and hepatopancreas samples, observing differences for some of these antioxidant enzymes between tissues analyzed. In the case of SOD, the IBR index showed that muscle and hepatopancreas obtained the higher activity of the enzyme for treatments at low salinity (lsBFT and lsCW), confirming this tendency with the ANOVA analyses only for hepatopancreas tissue and for both treatments $(P<0.05)$. Although IBR showed differences between tissues for the CAT activity, ANOVA recorded interaction between rearing system and salinity factors and maintaining a higher activity for lsBFT, followed by hsBFT, hsCW, and lsCW treatments $(P<0.05)$. SOD and CAT have an important role in protecting organisms against the oxidative stress produced by ROS. Furthermore, the 
SOD enzyme helps to prevent the formation of the lipid peroxidation initiator and the transformation of superoxide radicals $\left(\mathrm{O}_{2}^{-}\right)$to $\mathrm{H}_{2} \mathrm{O}_{2}$ and $\mathrm{O}_{2}$ (Tao et al. 2013), whereas the CAT enzyme is responsible for transforming these radicals into water $\left(\mathrm{H}_{2} \mathrm{O}\right)$ and molecular oxygen $\left(\mathrm{O}_{2}\right)$ (Cardona et al. 2015).

It has been demonstrated that some microbial communities in the BFT rearing system can influence the redox state in shrimp ( $\mathrm{Ju}$ et al. 2008, da Silva Martins et al. 2015). In this study, the higher LPO and PO in hepatopancreas and muscle of shrimp reared at high and low salinity, respectively $(P<0.05)$, could be related to a failure of the antioxidant system to counteract free radicals (Castex et al. 2010, Ren et al. 2015). Although high salinity treatments recorded a percentage of survival less than $80 \%$ (57\% for hsBFT, $60 \%$ for $\mathrm{hsCW}$ ), the weight gain and HSI were higher in comparison to the treatments reared at low salinity (lsBFT, lsCW), which reflected the higher LPO and PO values when the IBR index was performed. These results suggest that the oxidative damage could be different between tissues analyzed due to changes in the antioxidant composition in muscle and hepatopancreas (Da Silva Martins et al. 2015). It is possible to assume that the tissue factor affected LPO and PO values recorded because the water salinity also played an important role in the results

\section{CONCLUSION}

The results obtained in this study suggest that shrimp in BFT showed higher growth and adaptability to the rearing system conditions than those reared at $\mathrm{CW}$ (regardless of the water salinity). In addition, the low survival and growth for treatments at low salinity resulted from a low potassium and magnesium concentration in water. For this reason, this study supports the criteria to add these elements as a fertilizer to increase the freshwater quality used for inland shrimp farms. The nutritional and microbiological characteristics of BFT could have reduced stress, stimulating the antioxidant system through a greater activity of the enzymes in penaeid shrimp. Furthermore, the methodology used in this study suggests the use of muscle and hepatopancreas tissues to determine the antioxidant composition and possible oxidative damage in penaeid shrimp. It was possible to observe a significant increase of oxidative damage only in shrimp reared in clear water than those reared in BFT; using this methodology.

\section{ACKNOWLEDGMENTS}

The authors thank the financial support of the government of Brazil through the Program of Students in Agreement for Post-Graduation (PEC-PG) and the Coordination for the Improvement of Higher-Level Personnel (Brasil-CAPES) Finance Code 001 and the Project DGAPA-UNAM \#221316. We would like to thank M. in A. Miguel Arevalo for his support in capturing the wild juveniles. We would also like to thank Biol. Karen Ortega for the technical support during the laboratory work and M. in C. Eduardo Pacheco for his help with the statistical analyses.

\section{REFERENCES}

Aguilera-Rivera, D., Prieto-Davó, A., Rodríguez-Fuentes, G., Escalante-Herrera, K.S. \& Gaxiola, G. 2019a. A vibriosis outbreak in the Pacific white shrimp, Litopenaeus vannamei reared in biofloc and clear seawater. Journal of Invertebrate Pathology, 167: e107246. doi: 10.1016/j.jip.2019.107246

Aguilera-Rivera, D., Prieto-Davó, A., Escalante, K., Chávez, C., Cuzon, G. \& Gaxiola, G. 2014. Probiotic effect of floc on Vibrios in the Pacific white shrimp Litopenaeus vannamei. Aquaculture, 424-425: 215219. doi: 10.1016/j.aquaculture.2014.01.008

Aguilera-Rivera, D., Rodríguez-Fuentes, G., EscalanteHerrera, K.S., Guerra-Castro, E., Prieto-Davó, A. \& Gaxiola, G. 2019b. Differential expression of immunerelated genes in Pacific white shrimp, Litopenaeus vannamei, previously reared in biofloc and challenged with Vibrio harveyi. Aquaculture Research, 8: 20392046. doi: 10.1111/are.14063

Aguilera-Rivera, D., Escalante-Herrera, K., Gaxiola G, Prieto-Davó, A., Rodríguez-Fuentes, G., Guerra-Castro, E., et al. 2018. Immune response of the Pacific white shrimp, Litopenaeus vannamei, previously reared in biofloc and after an infection assay with Vibrio harveyi. Journal of the World Aquaculture Society, 50: 119-136. doi: 10.1111/jwas. 12543

American Public Health Association (APHA). 2012. Standard methods for examination of water and waste water. American Public Health Association Press, Washington DC.

Arreguín-Sánchez, F., Schultz-Ruíz, L.E., Gracia, A., Sánchez, J.A. \& Alarcón, T. 1997. Estado actual y perspectivas de las pesquerías de camarón. In: FloresHernández, D., Sánchez-Gil, P., Seijo, J.C. \& Arreguín-Sánchez, F. (Eds.). Análisis y diagnóstico de los recursos pesqueros críticos del Golfo de México. Universidad Autónoma de Campeche, EPOMEX Serie Científica, 7: 185-203.

Atwood, H.L., Young, S.P., Tomasso, J.R. \& Browdy, C.L. 2003. Survival and growth of Pacific white shrimp Litopenaeus vannamei postlarvae in lowsalinity and mixed-salt environments. Journal of the 
World Aquaculture Society, 34: 518-523. doi: 10.1111/ j.1749-7345.2003.tb00091.x

Avnimelech, Y. 1999. Carbon-nitrogen ratio as a control element in aquaculture systems. Aquaculture, 176: 227-235. doi: 10.1016/S0044-8486(99)00085-X

Avnimelech, Y. 2007. Feeding with microbial flocs by tilapia in minimal discharge bioflocs technology ponds. Aquaculture, 264: 140-147. doi: 10.1016/j. aquaculture.2006.11.025

Avnimelech, Y. \& Kochba, M. 2009. Evaluation of nitrogen uptake and excretion by tilapia in biofloc tanks, using ${ }^{15} \mathrm{~N}$ tracing. Aquaculture, 287: 163-168. doi: 10.1016/j.aquaculture.2008.10.009

Avnimelech, Y., Verdegem, M.C.J., Kurup, M. \& Keshavanath, P. 2008. Sustainable land-based aquaculture: rational utilization of water, land and feed resources. Mediterranean Aquaculture Journal, 1: 4555. doi: 10.21608/maj.2008.2663

Azim, M.E. \& Little, D.C. 2008. The biofloc technology (BFT) in indoor tanks: water quality, biofloc composition, and growth and welfare of Nile tilapia Oreochromis niloticus. Aquaculture, 283: 29-35. doi: 10.1016/j.aquaculture.2008.06.036

Bachére, E., Mialhe, E., Noël, D., Boulo, V., Morvan, A. \& Rodríguez, J. 1995. Knowledge and research prospect in marine mollusk and crustacean immunology. Aquaculture, 132: 17-32. doi: 10.1016/00448486(94)00389-6

Ballester, E.L.C., Wasielesky, J.W., Olivera-Cavalli, R. \& Abreu, P.C. 2007. Nursery of pink shrimp Farfantepenaeus paulensis in cages with artificial substrates biofilm composition and shrimp performance. Aquaculture, 269: 355-362. doi: 10.1016/j.aquaculture. 2007.04.003

Beliaeff, B. \& Burgeot, T. 2002. Integrated biomarker response: a useful tool for ecological risk assessment. Environmental Toxicology and Chemistry, 21: 13161322.

Boyd, C.E. \& Thunjai, T. 2003. Concentrations of major ions in waters of inland shrimp farms in China, Ecuador, Thailand and United States. Journal of the World Aquaculture Society, 34: 524-532.

Bradford, M.M. 1976. A rapid and sensitive method for the quantitation of microgram quantities of protein utilizing the principle of protein-dye binding. Analytical Biochemistry, 72: 248-254. doi: 10.1016/ 0003-2697(76)90527-3

Briggs, M., Funge-Smith, S., Subasinghe, R.P. \& Phillips, M. 2005. Introducciones y movimiento de dos especies de camarones peneidos en Asia y el Pacífico. FAO Documento Técnico de Pesca, 476: 86 pp.

Campos, B.R., Miranda-Filho, K., D'Incao, F., Poersch, L. \& Wasielesky, W. 2012. Acute toxicity of ammonia, nitrite and nitrate in pink shrimp juveniles
Farfantepenaeus brasiliensis (Latreille, 1817) (Crustacea: Decapoda). Atlântica, 34: 75-81.

Cardona, E., Lorgeoux, B., Chim, L., Goguenheim, J., Le Delliou, H. \& Cahu, C. 2015. Biofloc contribution to antioxidant defense status, lipid nutrition and reproductive performance of broodstock of the shrimp Litopenaeus stylirostris: consequences for the quality of eggs and larvae. Aquaculture, 452: 252-262. doi: 10.1016/j.aquaculture.08.003

Castex, M., Lemaire, P., Wabete, N. \& Chim, L. 2010. Effect of probiotic Pediococcus acidilactici on antioxidant defenses and oxidative stress of Litopenaeus stylirostris under Vibrio nigripulchritudo challenge. Fish and Shellfish Immunology, 28: 622-631. doi: 10.1016/j.fsi.2009.12.024

Castille, F.J.R. \& Lawrence, A. 1980. A comparison of the capabilities of juvenile and adult Penaeus setiferus and Penaeus stylirostris to regulate the osmotic sodium and chloride concentrations in the hemolymph. Comparative Biochemistry and Physiology - Part A: Physiology, 68: 677-680. doi: 10.1016/0300-9629(81) 90378-9

Chapman, R.W., Browdy, C.L., Savin, S., Prior, F. \& Wenner, E. 2004. Sampling and evaluation of white spot syndrome virus in commercially important Atlantic penaeid shrimp stocks. Diseases of Aquatic Organisms, 59: 179-185. doi: 10.3354/dao059179

Contreras-Vergara, C.A., Valenzuela-Soto, E., GarcíaOrozco, K.D., Sotelo-Mundo, R.R. \& Yepiz-Plascencia, G. 2007. A Mu-class glutathione S-transferase from gills of the marine shrimp Litopenaeus vannamei: purification and characterization. Journal of Biochemistry and Molecular Toxicology, 21: 62-67. doi: 10.1002/ jbt.20162

Corteel, M., Dantas-Lima, J., Wille, M., Alday-Sanz, V., Pensaert, M., Sorgeloos, P. \& Nauwynck, H. 2012. Moult cycle of laboratory-raised Penaeus (Litopenaeus) vannamei and $P$. monodon. Aquaculture International, 20: 13-18. doi: 10.1007/s10499-011-9437-9

Cruz-Suárez, L.E., Tapia-Salazar, M., Nieto-López, M.G., Guajardo-Barbosa, C. \& Ricque-Marie, D. 2009. Comparison of Ulva clathrata and the kelps Macrocystis pyrifera and Ascophyllum nodosum as ingredients in shrimp feeds. Aquaculture Nutrition, 15: 421-430. doi: 10.1111/j.1365-2095.2008. 00607.x

Da Silva Martins, A.C., Artigas-Flores, J.A., Porto, C., Wasielesky, J.W. \& Monserrat, J.M. 2015. Antioxidant and oxidative damage responses in different organs of Pacific white shrimp Litopenaeus vannamei (Boone, 1931) reared in a biofloc technology system. Marine and Freshwater Behaviour and Physiology, 48: 279-288. doi: 10.1080/10236244.2015.1041240 
Davis, D.A., Boyd, C.E., Rouse, D.B. \& Saoud, I.P. 2005. Effects of potassium, magnesium and age on growth and survival of Litopenaeus vannamei post-larvae reared in inland low salinity well waters in west Alabama. Journal of the World Aquaculture Society, 36: 403-406. doi: 10.1111/j.1749-7345.2005.tb003 46.x

Davis, D.A., Saoud, I.P., McGraw, W.J. \& Rouse, D.B. 2002. Considerations for Litopenaeus vannamei reared in inland low salinity waters. In: Cruz-Suárez, I.E., Ricque-Marie, D., Tapia-Salazar, M., Gaxiola-Cortés, M.G. \& Simoes, N. (Eds.). Avances en nutrición acuícola. Memorias del VI Simposium Internacional de Nutrición Acuícola, Cancún, pp. 73-90.

De Souza, D.M., Kutter, M.T., Furtado, P.S., Romano, L.A., Junior, W.W., Monserrat, J.M. \& Garcia, L. 2019. Growth, antioxidant system, and immunological status of shrimp in bioflocs and clear water culture system. Pesquisa Agropecuária Brasileira, 54: e00363. doi: 10.1590/S1678-3921.pab2019.v54.00363

Ebeling, J.M., Timmons, M.B. \& Bisogni, J.J. 2006. Engineering analysis of the stoichiometry of photoautotrophic, autotrophic and heterotrophic removal of ammonia-nitrogen in aquaculture systems. Aquaculture, 257: 346-358. doi: 10.1016/j.aquaculture.2006. 03.019

Ekasari, J., Zairin, J.M., Putri, D.U., Sari, N.P., Surawidjaja, E.H. \& Bossier, P. 2013. Biofloc based reproductive performance of Nile tilapia Oreochromis niloticus broodstock. Aquaculture Research, 46: 509512. doi: 10.1111/are. 12185

Emerenciano, M., Cuzon, G., Goguenheim, J. \& Gaxiola, G. 2012. Floc contribution on spawning performance of blue shrimp Litopenaeus stylirostris. Aquaculture Research, 44: 75-85. doi: 10.1111/j.1365-2109.2011. 03012.x

Fox, J.G., Dewhirst, F.E., Tully, J.G., Paster, B.J., Yan, L., Taylor, N.S., et al. 1994. Helicobacter hepaticus sp. nov., a microaerophilic bacterium isolated from livers and intestinal mucosal scrapings from mice. Journal of Clinical Microbiology, 32: 1238-1245.

Gandy, R.L, Samocha, T.M., Jones, E.R. \& McKee, D.A. 2001. The Texas live bait shrimp market. Journal of Shellfish Research, 20: 365-367.

Gaxiola, G., Arena, L., Aragón, H., Emerenciano, M., Maldonado, J.C., Concha, W., et al. 2008. Some aspects of feeding and nutrition of native Farfantepenaeus duorarum. In: Cruz-Suárez, L.E., Ricque-Marie, D., Salazar, M.T., López, M.G., Villareal-Cavazos, D.A., Lazo, J.P. \& Viana, M.T. (Eds.). Avances en nutrición acuícola. Memorias del IX Simposium Internacional de Nutrición Acuícola, Monterrey, pp. 410-420.

Garcia, A. \& Vázquez-Bader, R. 1998. The effects of artisanal fisheries on penaeid shrimp stocks in the Gulf of Mexico. In: Funk, F., Quinn II, T.J., Heifetz, J., Ianelli, J.N., Powers, J.E., Schweigert, J.F., et al. (Eds.). Symposium on fishery stock assessment models. Alaska Sea Grant College Program. American Fisheries Society, 15: 977-998. doi: 10.4027/fsam. 1998.54

Hadwan, M.H. \& Abed, H.N. 2016. Data supporting the spectrophotometric method for the estimation of catalase activity. Data in Brief, 6: 194-199. doi: 10.1016/j.dib.2015.12.012

Intergovernmental Oceanographic Commission (IOC). 1983. Chemical methods for use in marine environmental monitoring. Manuals and guides. UNESCO, Paris.

Jiang, D.H., Lawrence, A.L., Neil, W.H. \& Gong, H. 2000. Effects of temperature and salinity on nitrogenous excretion by Litopenaeus vannamei juveniles. Journal of Experimental Marine Biology and Ecology, 253: 193-209. doi: 10.1016/S0022-0981(00)00259-8

Ju, Z.Y., Forster, I., Conquest, L. \& Dominy, W. 2008. Enhanced growth effects on shrimp (Litopenaeus vannamei) form inclusion of whole shrimp floc or floc fractions to a formulated diet. Aquaculture Nutrition, 14: 533-543. doi:10.1111/j.1365-2095.2007. 00559.x

Kuhn, D.D., Boardman, G.D., Craig, R., Flick Jr., G.J. \& McLean, E. 2008. Use of microbial flocs generated from tilapia effluent as a nutritional supplement for shrimp, Litopenaeus vannamei, in recirculating aquaculture systems. Journal of the World Aquaculture Society, 39: 72-82. doi: 10.1111/j.1749-7345.2007. 00145.x

Kumlu, M., Eroldogan, O.T. \& Aktas, M. 2000. Effect of temperature and salinity on larval growth, survival and development of Penaeus semisulcatus. Aquaculture, 188: 167-173. doi: 10.1016/S0044-8486(00)00330-6

Laramore, S., Laramore, C.R. \& Scarpa, J. 2001. Effect of low salinity on growth and survival of postlarvae and juvenile Litopenaeus vannamei. Journal of the World Aquaculture Society, 32: 385-392. doi: 10.1111/j. 1749-7345.2001.tb00464.x

LeMoullac, G., Soyez, C., Saulnier, D., Ansquer, D., Avarre, J. \& Levy, P. 1998. Effect of hypoxic stress on the immune response and the resistance to vibriosis of the shrimp Penaeus stylirostris. Fish and Shellfish Immunology, 8: 621-629. doi: 10.1006/fsim.1998. 0166

Lin, Y.C. \& Chen, J.C. 2001. Acute toxicity of ammonia on Litopenaeus vannamei (Boone) juveniles at different salinity levels. Journal of Experimental Marine Biology and Ecology, 259: 109-119. doi: 10.1016/S0022-0981(01)00227-1

McNevin, A.A., Boyd, C.E., Silapajarn, O. \& Silapajarn, K. 2004. Ionic supplementation of pond waters for 
inland culture of marine shrimp. Journal of the World Aquaculture Society, 35: 460-467. doi: 10.1111/j. 1749-7345.2004.tb00111.x

Mesquita, C.S., Oliveira, R., Bento, F., Geraldo, D., Rodríguez, J. \& Marcos, J.C. 2014. Simplified 2,4 dinitrophenylhydrazine spectrophotometric assay for quantification of carbonyls in oxidized proteins. Analytical Biochemistry, 458: 69-71. doi: 10.1016/j. ab.2014.04.034.

Moya, M., Lawrence, A.L., Collins, C.A. \& Samocha, T.M. 1999. Acclimation of Penaeus vannamei postlarvae to $2 \mathrm{ppm}$ ground saline water in Sonora Desert, Arizona. World Aquaculture Society, Baton Rouge.

Muñoz, M., Cedeño, R., Rodriguez, J., Knaap, W.P.W., Mialhe, E. \& Bachere, E. 2000. Measurement of reactive oxygen intermediate production in haemocytes of penaeid shrimp, Penaeus vannamei. Aquaculture, 19: 89-107. doi: 10.1016/S0044-8486 (00)00420-8

Otoshi, C.A., Montgomery, A.D., Look, A.M. \& Moss, S.M. 2001. Effects of diet and water source on the nursery production of Pacific white shrimp Litopenaeus vannamei. Journal of the World Aquaculture Society, 32: 243-249. doi: 10.1111/j.17497345.2001.tb00378.x

Pascual, C., Sánchez, A., Sánchez, A., Vargas-Albores, F., LeMoullac, G. \& Rosas, C. 2003. Haemolymph metabolic variables and immune response in Litopenaeus setiferus adult males: the effect of an extreme temperature. Aquaculture, 218: 637-650. doi: 10.1016/S0044-8486(02)00300-9

Prangnell, D.I. \& Castro, L.F. 2016. Some limiting factors in superintensive production of juvenile Pacific white shrimp, Litopenaeus vannamei, in no-water-exchange, biofloc-dominated systems. Journal of the World Aquaculture Society, 47: 396-413. doi: 10.1111/jwas. 12275

Quiu, J., Wang, W.N., Wang, L.J., Liu, Y.F. \& Wang, A.L. 2011. Oxidative stress, DNA damage and osmolality in the Pacific white shrimp, Litopenaeus vannamei, exposed to acute low-temperature stress. Comparative Biochemistry and Physiology - Part C: Toxicology \& Pharmacology, 154: 36-41. doi: 10.1016/j.cbpc.2011.02.007

R Core Team. 2018. R: A language and environment for statistical computing. R Foundation for Statistical Computing. [http://www.R-project.org]. Reviewed: March 12, 2020.

Ren, X., Pan, L. \& Wang, L. 2015. The detoxification process, bioaccumulation, and damage effect in juvenile white shrimp Litopenaeus vannamei exposed to chrysene. Ecotoxicology and Environmental Safety, 114: 44-51. doi: 10.1016/j.ecoenv.2015.01.004
Ren, Q., Sun, R.R., Zhao, X.F. \& Wang, J.X. 2009. A selenium-dependent glutathione peroxidase (Se-GPx) and two glutathione S-transferases (GSTs) from Chinese shrimp (Fenneropenaeus chinensis). Comparative Biochemistry and Physiology - Part C: Toxicology \& Pharmacology, 149: 613-623. doi: 10.1016/ j.cbpc.2009.01.007

Rosas, C., Cooper, E.L., Pascual, C., Brito, R., Gelabert, R., Moreno, T., et al. 2004. Indicators of physiological and immunological status of Litopenaeus setiferus wild populations (Crustacea: Penaeidae). Marine Biology, 145: 401-413. doi: 10.1007/s00227-0041321-y

Roy, L.A., Davis, D.A., Saoud, I.P. \& Henry, R.P. 2007. Effects of varying levels of aqueous potassium and magnesium on survival, growth, and respiration of the Pacific white shrimp, Litopenaeus vannamei, reared in low salinity waters. Aquaculture, 262: 461-469. doi: 10.1016/j.aquaculture.2006.10.011

Roy, L.A., Davis, D.A., Saoud, P., Boyd, C.A., Pine, H.J. \& Boyd, C.E. 2010. Shrimp culture in inland low salinity waters. Reviews in Aquaculture, 2: 191-208. doi: 10.1111/j.1753-5131.2010.01036.x

Rozas, L.P. \& Minello, T.J. 2011. Variation in penaeid shrimp growth rates along an estuarine salinity gradient: implications for managing river diversions. Journal of Experimental Marine Biology and Ecology, 397: 196-207. doi: 10.1016/j.jembe.2010.12.003

Samocha, T.M., Burkott, B.J., Lawrence, A.L., ShengJuan, Y., Jones, E.R. \& McKee, D.A. 1998. Management strategies for production of the Atlantic white shrimp Penaeus setiferus as bait shrimp in outdoor ponds. Journal of the World Aquaculture Society, 29: 211-220. doi: 10.1111/j.1749-7345.1998. tb00979.x

Samocha, T.M., Prangnell, D.I., Hanson, T.R., Treece, G.D., Morris, T.C., Castro, L.F. \& Staresinic, N. 2017. Design and operation of -super intensive bioflocdominated systems for indoor production of the Pacific white shrimp, Litopenaeus vannamei. The Texas A\&M AgriLife Research Experience. The World Aquaculture Society, Baton Rouge.

Samocha, T.M., Patnaik, S., Speed, M., Ali, A.M., Burger, J.M., Almeida, R.V., et al. 2007. Use of molasses as carbon source in limited discharge nursery and growout systems for Litopenaeus vannamei. Aquacultural Engineering, 36: 184-191. doi: 10.1016/j.aquaeng. 2006.10.004

Sandifer, P.A., Hopkins, J.S., Stokes, A.D. \& Browdy, C.L. 1993. Preliminary comparisons of the native Penaeus setiferus and Pacific P. vannamei white shrimp for pond culture in South Carolina Journal of 
the World Aquaculture Society, 24: 295-303. doi: 10.1111/j.1749-7345.1993.tb00161.x

Saoud, I.P., Davis, D.A. \& Rouse, D.B. 2003. Suitability studies of inland well waters for Litopenaeus vannamei culture. Aquaculture, 217: 373-383. doi: 10.1016/S0044-8486(02)00418-0

Smith, R.A., Walker, T., Xie, X. \& Hou, S.T. 2003. ST involvement of the transcription factor $\mathrm{E} 2 \mathrm{~F} 1 / \mathrm{Rb}$ in kainic acid-induced death of murine cerebellar granule cells. Molecular Brain Research, 116: 70-79.

Soltes-Ferreira, G., Bolivar, N.C., Pereira, S.A., Guertler, C., do Nascimento-Vieira, F., Pedreira-Mouriña, J.L. \& Quadros-Seiffert, W. 2015. Microbial biofloc as source of probiotic bacteria for the culture of Litopenaeus vannamei. Aquaculture, 448: 273-279. doi: 10.1016/j.aquaculture.2015.06.00

Song, Y., Li, Z.X., Lin, H., Du, S.Y., Hao, Z., Lin, H.X. \& Zhu, Z. 2015. Effect of malondialdehyde treatment on the IgE binding capacity and conformational structure of shrimp tropomyosin. Food Chemistry, 175: 374-380. doi: 10.1016/j.foodchem.2014.12.001

Tacon, A.G.J., Cody, J.J., Conquest, L.D., Divakaran, S., Forster, I.P. \& Decamp. O.E. 2002. Effect of culture system on the nutrition and growth performance of Pacific white shrimp Litopenaeus vannamei (Boone) fed different diets. Aquaculture Nutrition, 8: 121-137. doi: 10.1046/j.1365-2095.2002.00199.x

Tao, Y., Hong-Liang, Z., Yin-Ming, H., Shuo, W. \& Zheng-Quan, S. 2013. Preparation of chitosan and water-soluble chitosan microspheres via spray-drying method to lower blood lipids in rats fed with high-fat diets. International Journal of Molecular Sciences, 14: 4174-4184. doi: 10.3390/ijms14024174

Valenzuela, M. 2009. Condição fisiológica e imunológica do camarão-rosa do Golfo do México Farfantepenaeus duorarum (Burkenroad, 1939) cultivado em Sistema BFT (Bio-Floc Technology). Programa de Pós-Graduação em Aqüicultura, Dissertação de Mestrado, Universidade Federal do Rio Grande, Rio Grande.

Valenzuela, M., Suárez, J., Sánchez, A. \& Rosas, C. 2002. Cultivo del camarón blanco del Golfo de México Litopenaeus setiferus en estanques de manto freático. II Congreso Nacional de la Asociación Mexicana de Limnología, Ciudad de México, pp. 1-9.

Received: 6 May 2020; Accepted: 4 March 2021
Van Wyk, P. \& Scarpa, J. 1999. Water quality and management. In: Van Wyk, P., Davis-Hodgkins, M., Laramore, R., Main, K.L., Mountain, J. \& Scarpa, J. (Eds.). Farming marine shrimp in recirculating freshwater systems. Florida Department of Agriculture and Consumer Services, Tallahassee, pp. 128-138.

Wakida-Kusunoki, A.T. \& Amador-Del Angel, L.E. 2011. Aspectos biológicos del pleco invasor Pterygoplichthys pardalis (Teleostei: Loricariidae) en el río Palizada, Campeche, México. Revista Mexicana de Biodiversidad, 82: 870-878.

Wasielesky Jr., W., Atwood, H., Stokes, A. \& Browdy, C.L. 2006. Effect of natural production in a zeroexchange suspended microbial floc-based superintensive system for white shrimp Litopenaeus vannamei. Aquaculture, 258: 396-403. doi: 10.1016/ j.aquaculture.2006.04.030

Xie, J., Zhao, Y., Wang, Q., Wu, H., Teng, J., Yang, D., et al. 2016. An integrative biomarker approach to assess the environmental stress in the north coast of Shandong Peninsula using native oysters, Crassostrea gigas. Marine Pollution Bulletin, 112: 318-326. doi: 10.1016/j.marpolbul.2016.07.049

Xu, W. \& Pan, L. 2013. Enhancement of immune response and antioxidant status of Litopenaeus vannamei juvenile in biofloc-based culture tanks manipulating high $\mathrm{C} / \mathrm{N}$ ratio of feed input. Aquaculture, 412-413: 117-124. doi: 10.1016/j.aquaculture.2013.07.017

Yuepeng, S., Shen, M. \& Feng, C. 2010. Effects of salinity fluctuation on the growth and energy budget of juvenile Litopenaeus vannamei at different temperatures. Journal of Crustacean Biology, 30: 430-434. doi: $10.1651 / 09-3269.1$

Zhao, D., Pan, L., Huang, F., Wang, C. \& Xu, W. 2016. Effects of different carbon sources on bioactive compound production of biofloc, immune response, antioxidant level, and growth performance of Litopenaeus vannamei in zero-water exchange culture tanks. Journal of the World Aquaculture Society, 47: 566-576. doi: 10.1111/jwas. 12292

Zhou, W.N., Wang, A.L., Wang, W.Y., He, Q.T. \& Zhou, Y.L. 2009. Glutathione S-transferasa in the white shrimp Litopenaeus vannamei: characterization and regulation under $\mathrm{pH}$ stress. Comparative Biochemistry and Physiology - Part C: Toxicology and Pharmacology, 150: 224-230. doi: 10.1016/j.cbpc.2009. 04.012 